\title{
1989. ON THE CONCEPT OF MODERNISM
}

In art history, the importance of divisions based on calendar and specific dates has been clearly decreasing, ${ }^{1}$ which is why, making 1989 my central point of reference, I must take a more inclusive look at my topic, i.e., the concept of modernism and changes of its meaning. The concept problematizes, the term puts in order. The meaning of a concept is determined by the changing proximate words on the mental map, therefore, writes Mieke Bal, it is a theory in miniature which points, argues Reinhart Koselleck, at a historico-philosophical horizon, and finally, is closely associated with the artistic or exhibition practice of a given scholar. ${ }^{2}$ When we choose concepts, the emotional aura of the word also plays a crucial role.

In my opinion, the evolution of the concept of modernism reveals the gist of changes in the Polish art of the last dozen years of the $20^{\text {th }}$ century and the beginning of the present one, confirming also a well-grounded scheme according to which Polish art history has been putting it in order. Even though statistics show that over the last few decades the concept of modernism did not appear in published texts too often - the "avant-garde" did, and "art of resistance/critical art" as well - still, it proved to have the most explanatory power. I will begin with setting temporal limits.

In 1976, Wiesław Juszczak published an anthology titled Teksty o malarzach. Antologia polskiej krytyki artystycznej 1890-1918 [Texts about Painters. Anthology of Polish Art Criticism, 1890-1918], and a year later a study

1 This is what I believe myself - I have been questioning the choice of 1945 as a threshold date in art. History even though it has been commonly accepted. See my essay "Pięć lat," in: Zaraz po wojnie, eds. J. Kordjak, A. Szewczyk, Warszawa 2015, pp. 32-44. The same refers to 1989. See my essay "Kiedy zaczęło się 'dzisiaj'? O źródłach sztuki polskiej lat dziewięćdziesiątych,” in: Sztuka dzisiaj, ed. M. Poprzęcka, Warszawa 2002, pp. 27-39.

2 See M. Bal, Traveling Concepts in the Humanities. A Rough Guide, Toronto 2002; R. Koselleck, Begriffsgeschichten. Studien zur Semantik und Pragmatik der politischen und sozialen Sprache, Berlin 2011. Both studies are very different from Władysław Tatarkiewicz's approach. 
called Malarstwo polskie: modernizm [Polish Painting: Modernism]. In fact, however, both books must be approached as a whole. ${ }^{3}$ A quarter of century later, two studies with the word "modernism" in their titles came out: in 1999, Znaczenia modernizmu. W stronę historii sztuki polskiej po 1945 roku [The Meanings of Modernism: Toward a History of Polish Art after 1945] by Piotr Piotrowski, and in 2000, Budowniczowie świata. Z dziejów radykalnego modernizmu w sztuce polskiej [Builders of the World. From the History of Radical Modernism in Polish Art] by Andrzej Turowski. Certainly, "modernism" in Piotrowski's book means something else than in Turowski's one, while both authors (close to each other due to their similar approaches to the concept's origin) differ from Juszczak who never accepted their understanding of the term.

A strong point of Juszczak's approach to modernism has been his analysis of paintings: thick description and grounded theory confirmed by the analysis of the idiom of criticism, to mention only luminism and intensivism. Moreover, Juszczak placed in the tradition of both reflection on history and on art the heritage of Jan Matejko and the Cracow conservatism of the late 19th century, as interpreted by Marcin Król. Elżbieta Grabska, a major scholar specializing in modern art, to whose work I will be referring below, distinguished among three meanings of the term "modernism." First, it was, just like for Juszczak, a synonym of the Young Poland (Młoda Polska). Second, it was the art of Vienna around 1910, according to Andrzej Olszewski. ${ }^{4}$ Third, "modernism" was close to the idea of modernity, at that time anachronistic and unclear, perhaps with the exception of "modernist architecture," also called so by Olszewski. Juszczak's approach did not undermine those distinctions but resulted in a rare, and maybe the first of its kind, deeply rooted in works of art and theoretically justified, interpretation of a current in modern Polish art.

A rejection, or perhaps reduction, of the semantic field of Juszczak's concept of modernism took place around 1989 in consequence of an invasion of postmodernism, which was first documented by literary scholars. ${ }^{5}$ In 1987 , the Polish translation of Postmodernist Architecture by Charles Jencks was published, and next year Marcin Giżycki published his influential antholo-

${ }^{3}$ Even though there ar emany studies on Polish modernism in plastic arts, they are incomparable to studies of literary scholars on literary modernism. Both books by Juszczak are far superior to other texts that deal with art at the turn of the $20^{\text {th }}$ century.

${ }^{4}$ A. Olszewski, Nowa forma w architekturze polskiej 1900-1925. Teoria i praktyka, Wrocław 1967.

5 See Odkrywanie modernizmu, ed. R. Nycz, Kraków 1998. An overview of the relations between the avant-garde and modernism can be found in J. Orska, Przełom awangardowy w dudziestowiecznym modernizmie w Polsce, Kraków 2004. 
gy of classic postmodernist theory, titled Postmodernizm - kultura wyczerpania? (Postmodernism - Culture of Exhaustion?). Giżycki introduced into Polish art history the Anglo-American perspective and made Polish scholars take into consideration a number of terms that ordered the panorama of contemporary art anew.

The appearance of postmodernism, which made us realize that we are not "within" but "without" modernity/modernism, had many consequences, not all of them surprising. One of the papers delivered during the annual session of the Association of Art Historians in 1984 was entitled "Nowoczesność i jej granice" [Modernity and Its Boundaries]. ${ }^{6}$ Postmodernism determined a new, for linguistic reasons quite obvious, interpretation of the word "modernism." Saving the word "modernity," which apparently started referring to the general worldview of the Enlightenment, Polish scholars began interpreting the concept of modernism according to Clement Greenberg as a specific artistic articulation of modernity. As a result, the problem of the autonomy of art became most prominent, which at the moment of a major political change in 1989 that continued in the 1990s, acquired political significance. A political qualification of, e.g., abstract art as autonomous and hence acceptable by the authorities, was proposed also earlier, for instance by Piotrowski, but in the final decade of the $20^{\text {th }}$ century it acquired a radically negative meaning. Contrary to the years following the period of martial law, when the evaluation of the art of the communist Poland was balanced - as for example at the 1984 conference - the next decade did not have any scruples in that respect.

Even this short and by no means complete list of topics determined by a new point of view on contemporary art (the consequences of the prefix "post-") reveals the problem's complexity. Does it really make sense to talk about postmodernity or rather, late modernity, as this is a key distinction in respect to the set of values concerning art? Is it legitimate to insist, particularly after the publication of the English translation of Peter Bürger's Theory of the Avant-Garde, that the idea of the autonomy of art clearly denied its subversive or at least provocative character? Finally, what are the meanings of commonly used term "modernity" and the renewed "modernism," with the latter becoming more and more influential also in Poland? And the most important question: what is the relation between modernism and avant-garde? All those questions were asked about thirty years ago and now answers to them are var-

${ }^{6}$ Another presentation, by Wojciech Lipowicz, which opened the proceedings volume, referred to the popular dichotomy of center vs margin, evidently favoring the latter. See "Nadąsani I zadumani," in: Sztuka polska po 1945 roku. Materiały Sesji Stowarzyszenia Historyków Sztuki, Warszawa, listopad 1984, ed. T. Hrankowska, Warszawa 1987, pp. 9-17. 
ious, supported by different arguments and theories, but back then they were a serious challenge which few scholars were ready to realize.

The most important attempt to put the modified lexicon in a new order and to draw new dividing lines on the map of Polish art in the $20^{\text {th }}$ century was Piotr Piotrowski's study Znaczenia modernizmu. W strone historii sztuki polskiej po 1945 roku, originally announced under the title Dialektyka modernizmu [Dialectic of Modernism]. Piotrowski made three crucial decisions. First, following Peter Bürger, he defined modernism as autonomous art, in fact including in his definition the whole range of meanings characteristic of modernity. ${ }^{7}$ Consequently, modernism was identified with modern art in general (hence Juszczak's objection), autonomous in terms proposed by Greenberg. Piotrowski aptly remarked that Greenberg's well-known essay should be titled "Modernism and Kitsch." Second, all the art so far referred to as the avant-garde was placed under the label "modernism" as well. Piotrowski's argument was that the idea of the avant-garde changed its meaning under the influence of politically radical art called critical. ${ }^{8}$ A claim that the critical art determined a new order in the lexicon of Polish art history was Piotrowski's third resolution. As a result, the idea of the avant-garde became historical and lost its significance in favor of the critical art which in the 1990s had its heyday. That established a new ranking of radicalism, for Piotrowski identical with the general hierarchy of value - the critical art got ahead of the avant-garde and left modernism far behind.

Therefore, such artists as Władysław Strzemiński and Henryk Stażewski, traditionally classified by Polish art historians as avant-gardists, turned into modernists in the new sense of the term proposed in Znaczenia modernizmu. ${ }^{9}$ Piotrowski's terminological innovations coincided with his curatorial experience with Zofia Kulik's exhibition organized in 1997 in the National Museum in Poznań, as well as the inspiration of Hal Foster, whose texts were widely read in Poland in the 1990s. (Foster's essay, "For a Concept of the Political in Art," was translated into Polish in 1994. ${ }^{10}$ ) In a sense, Mariusz Bryl's extraordinary book Suwerenność dyscypliny. Polemiczna historia historii sztuki od 1970 roku [Sovereignty of the Discipline. Polemical Art History since 1970], published in 2008, supported and confirmed

7 P. Piotrowski, Znaczenia modernizmu. W strone historii sztuki polskiej po 1945 roku, Poznań 1999, p. 80.

${ }^{8}$ Ibidemi, p. 10.

9 Ibidem, pp. 117-146.

10 Magazyn Sztuki 1994, 4. Foster's essay was translated by Ewa Mikina, an expert on English language literature on contemporary art. 
a new dichotomy. In his "Conclusion," Bryl, whose theoretical expertise was unprecedented in Poland, placed the new opposition in a binary frame of criticism and modernist essentialism.

Even though it reaches beyond my chronological framework, further evolution of the terms "modernism" and "avant-garde" in Piotrowski's writing seems worth following on the present occasion. His next book, Awangarda w cieniu Jałty [Avant-Garde in the Shadow of Yalta], published in 2005, both announced and illustrated his next project, presented in more detail in his essay "O horyzontalnej historii sztuki" [On the Horizontal Art History]. ${ }^{11}$ The two text are incomparable in length, but are important for my argument since they refer to the representations of the avant-garde and modernist art drawn from other methodological experience and research traditions. The use of the term "avant-garde" in the title was determined by the necessity to take into consideration the perspectives of both Western and Eastern European scholars. A horizontal approach, opposing the dominant vertical and Western view of modern art, in Piotrowski's texts still referred to the "verti$\mathrm{cal}^{\prime \prime}$ order of the avant-garde, though it also encompassed all Eastern Europe. His local point of view did not affect the adopted paradigm of critical values: innovation (progress) vs resistance. Piotrowski might have needed a new, unambiguous qualification of the term "modernism" as understood in 1999 more to depreciate traditional painting (painting on canvas, he claimed elsewhere, "supports the political status quo") and boost the radicalism of the critical art, than to make the concept of the avant-garde somewhat less general. That approach was apparently confirmed in his posthumously published book, Globalne ujęcie sztuki Europy Wschodniej [A Global Approach to the Art of Eastern Europe]. In this book, focused on geoartistic relations and postcolonial revisions, the concept of the avant-garde is equaled with that of modernity: the term "modernism" sometimes means "avant-garde" and on other occasions just "modernization." The argument is not too pedantic, as usual in terminological disputes, but the study does not place terminology in the foreground, either.

The changes of the meaning of modernism must not be considered apart from the changing concept of the avant-garde since they are closely interrelated. To begin with, a short, historical introduction seems indispensable. The concept of the avant-garde as a phenomenon characteristic of modern Polish art was introduced in 1949 by Mieczysław Porębski in his essay "Dwa programy" [Two Programs], published at the climax of a fierce artistic-po-

${ }^{11}$ Artium Quaestiones 2009, 20, pp. 59-73. 
litical conflict. ${ }^{12}$ The author established an unshakable binary paradigm in which broadly understood avant-garde that had different variants depending on a given period always occupied a crucial position. In 1949, Porębski identified it with modernity defined as critical judgment of reality, and made its meaning clear by opposing it to colorism. That retroactive aspect of "modernity," connected to the prewar "Grupa Krakowska" [Cracow Group], was effectively eliminated in Poland in the late 1950s. Since then, with a few minor exceptions, the avant-garde always owed its significance to the contrast with its opponents: after colorism, those were formalism, realism, sometimes pictural abstraction, etc. In the mid-1970s, when the neo-avant-garde was in decline, the official periodical Sztuka made the avant-garde equal in rights to realism. ${ }^{13}$

To generalize, Piotrowski considered engaged criticism with a political bias the main point of reference for most terms he used. In his opinion, public engagement should match and be a supplement of the academic activity. It seems that the political aspect, instead of transgression or utopianism, was for him the most important as an element of his definition of the avant-garde. This particular point of view makes Piotrowski's approach different from that of Turowski who, like no other scholar but Porębski, favored the avant-garde as the leading narrative of Polish art. Turowski did not use the concept of modernism in Piotrowski's sense: in his Konstruktywizm polski. Próba rekonstrukcji nurtu (1921-1934) [Polish Constructivism. A Tentative Reconstruction, 1921-1934], written in 1969-1971 and published in 1981, he approached constructivism as a component of the avant-garde., which was quite obvious, in tune with the secondary literature of those times.

During the decade between the completion of the book and its publication, Turowski changed his opinion. First, when for some time he was connected to the Foksal Gallery in Warsaw, he located the constructivist tradition in the French leftist context of May 1968, which, as he put it, "rejected form in favor

12 Porębski's presentation, delivered during „Popisy szkół artystycznych” in 1949 in Poznań, was published in Materiały do Studiów i Dyskusji z Zakresu Teorii i Historii Sztuki, Krytyki Artystycznej oraz Metodologii Badań nad Sztuka, vol. 1. Warszawa 1950, pp. 51-76.

13 See also M. Spychalski, "Na straży awangardy," Odra 2014, 4; W. Włodarczyk, "Artysta nowoczesny jako t.w.," Miejsce. Studia nad sztuka i architektura XX i XXI wieku 2015, 1, pp. 89-108. In my opinion, Andrzej Turowski was forced to change the title of his book from Rewolucja konstruktywistyczna [The Constructivist Revolution] to W kregu konstruktywizmu, Warszawa 1979, because at that moment in the history of communist Poland censorship did not approve of the term "revolution," not because constructivism was of the avant-garde character. 
of action." ${ }^{14}$ Second, he was inspired by structuralism - Janusz Sławiński's seminal study of the poetic idiom of the Cracow avant-garde was published in 1965. Third, another influence on Turowski were the exhibitions organized in the Museum of Art in Łódź, whose director since 1966 was Ryszard Stanisławski. (Particularly significant were the exhibitions titled "Konstruktywizm polski," showed in Otterlo and Essen in 1973. ${ }^{15}$ ) Stanisławski's connection of the work of Władysław Strzemiński with that of Katarzyna Kobro, with all the due responsibility and authority of the museum, cannot be overrated and must not be ignored whenever the concept of the avant-garde is examined next to others in use at that time. Stanisławski's strategy significantly endorsed Porębski's statement made in his "Dwa programy" essay. Wiesław Borowski's essay "Pseudoawangarda" (1975), which Turowski highly appreciated, just as Piotrowski in his book Dekada [Decade], should be considered in this neo-avant-garde perspective of canonizing the Polish avant-garde between the world wars and institutionalizing Polish constructivism in an international context. ${ }^{16}$

In the 1980s and 1990s, many publications on the avant-garde appeared in Poland. At first, they were related to the decline of the neo-avant-garde, then they were dealing with postmodernism. ${ }^{17}$ Most of Turowski's texts from the final years of the $20^{\text {th }}$ century dealt with the avant-garde. Also he changed his critical opinion about the so-called pseudo-avant-garde, ${ }^{18}$ since under the circumstances they were hard to adhere to. Still, he chose for his second major work, Budowniczowie świata, the subtitle "radical modernism." In that book, Turowski elaborated on an idea included in "Granice awangardy" [The Limits of the Avant-Garde], published in 1990 as a chapter of Wielka utopia awangardy. Artystyczne i społeczne utopie w sztuce rosyjskiej 1910-1930 [The Great Utopia of the Avant-Garde. Artistic and Social Utopias in Russian Art, 1910-193]. In Budowniczowie świata he rejected his earlier idea of constructivism-as-avant-garde, inspired by structuralism, museums, and the academic tradition, later modified with utopia, in favor of the postmodernist poetics of the fall and death. That turn in Turowski's thinking, from the

14 A. Turowski, Konstruktywizm polski. Próba rekonstrukcji nurtu (1921-1934), Wrocław 1981, p. 233.

${ }^{15}$ Ibidem, pp. 240-241.

16 W. Borowski, "Pseudoawangarda," Kultura 1975, 12.

17 Particularly important in this context are essays by Stefan Morawski, e.g, his "O słabościach praxis neoawangardowej i niedostatkach teorii awangardy," in: Wybory i ryzyka awangardy. Studia z teorii awangardy, eds. U. Czartoryska, R. W. Kluszczyński, WarszawaŁódź 1985, pp. 7-26.

18 A. Turowski, Awangardowe marginesy, Warszawa 1998, p. 172. 
diverse but still academic approaches to the avant-garde to postmodernist license and a comeback of the obsolete, historical meaning of the term due to ambiguous playing with it, was later confirmed in his other book, Parowóz dziejów [The Locomotive of History] from 2012. ${ }^{19}$

However, it seems that after the 1990s, when the term "avant-garde" was ubiquitous, supplementing the title of Budowniczowie świata with "modernism" was not surprising. On the one hand, postmodernism and the critical art, and on the other, its proximity or even identification with the socialist realism, often discussed in scholarly studies, did not make the concept of the avant-garde attractive and useful in research, while "radical modernism" was also historically justified..$^{20}$ In the 1920s, such concepts as modernism, radical modernism, new art, and, rarely, the avant-garde, were used interchangeably and the examination of their relations brings today surprising and often subversive results.

At the beginning of the $21^{\text {st }}$ century, with continuing ambiguities and terminological shifts related to a number of "turns" in the humanities, another important Polish publication, almost unnoticed by the academic audience, was "Moderne" i straż przednia. Apollinaire wśród krytyków i artystów 1900-1918 ["Moderne" and the Avant-Garde. Apollinaire among Critics and Artists, 1900-1918] by Elżbieta Grabska. Its subject matter was the identity of two attitudes: the modernist and the avant-garde one, with the focus on France and Italy, where the idea of the avant-garde came into being also in the linguistic sense. The book provided an extra argument that the origin of the concept of the avant-garde and today's understanding of its historical context are of primary importance. It should be noted that the apparently "avant-gar$\mathrm{de}^{\prime \prime}$ artist and theorist Mieczysław Szczuka in the final stage of his career criticized in the journal Dźwignia small, minimalistic apartments and the socially engaged leftist architects from the Praesens group. In the late 1960s and early 1970s, during a neo-avant-garde offensive, avant-gardism became part of the official policy of the authorities, confirmed by the aforementioned essay published in Sztuka, but not only. Finally, the Polish Parliament issued

19 A. Turowski, Parowóz dziejów, Warszawa 2012.

${ }^{20}$ For critical remarks on the relations of the avant-garde with the socialist realism, see S. Morawski, Na zakręcie od sztuki do po-sztuki, Kraków 1985, p. 272. On the relations of the avant-garde and the socialist realism, see W. Włodarczyk, Socrealizm. Sztuka polska w latach 1950-1954, Paris 1986; B. Groys, Gesamtkunstwerk Stalin, München 2008. Ryszard Kluszczyński, who was probably the first to use the term "critical art," interpreted the avant-garde in terms of Russian formalism, see R. Kluszczyński, Awangarda - rozważania teoretyczne, Łódź 1997. 
in 2017 a resolution to commemorate "100 years of the avant-garde," about which many contemporary art historians were quite skeptical. ${ }^{21}$

Thus, an important decision made by Piotrowski in his Znaczenia modernizmu to promote lexical and conceptual shifts and assign new terms to some referents shows the defects of contemporary art history in Poland, caused by its ungrounded and arbitrary choice of research objects, terminological chaos, and disregard for the deeper meaning of the terms used, whose only function is to bring some kind of superficial order. To return to Juszczak's Malarstwo polskie: modernizm: the scholar's protest was not provoked by simple appropriation of "modernism," but by the basic meaning of the term that he connected with the turn of the $20^{\text {th }}$ century. For Juszczak, modernism was a grand finale of the epoch of Matejko and History. Polish identity was formed by the complex of the lost statehood, and it keeps coping with this problem today also. In 1803, Bishop Jan Paweł Woronicz called their language the proper motherland of Poles and we are still dealing with the consequences of that fact, which has been demonstrated by Maria Janion or Agata Bielik-Robson. ${ }^{22}$ Language as well as all the other cultural media, as the domain of political identity determined in the first half of the $19^{\text {th }}$ century and the myth of History from its second half, contributed to a mental model of the artist-intellectual, which was put to an end by the revolution of 1905. The concept of modernism from Juszczak's book refers to that state of intellectual inadequacy and helplessness before the pressing social forces, indicating a gradual collapse of the nineteenth-century cultural project.

Are we now, almost twenty years into the $21^{\text {st }}$ century, distanced enough to see the previous age in terms of similar, general and ordering, rules of the cultural code and ask why the avant-garde or modernist, also in the revised sense, narratives are dominant in the studies of contemporary Polish art? Znaczenia modernizmu by Piotrowski did not change but supported the fifty-year old dichotomy introduced by Porębski, now as an opposition of modernism and the critical art. I will start from the end. The second half of the $20^{\text {th }}$ century - the era of the communist Poland - brought about accelerated modernization which was socially traumatic and stigmatizing for its opponents as well as economically catastrophic and socially controversial. It was then, in the 1960s - a decade of reflection on history, a dream of modernity

${ }^{21}$ Resolution of the Parliament of the Republic of Poland of December 14, 2017 „on the celebration of Polish avant-garde on the centennial of its inauguration." Doubts were provoked primarily by the arguments used and the list of artists.

22 See also R. Przybylski, Klasycyzm, czyli prawdziwy koniec Królestwa Polskiego, Warszawa 1983. 
and order exemplified by progress and structuralism - that the avant-garde key to a simplified model of the Polish condition became prevalent as a projection of longing, but also of the failure of modernization as a specific "historical policy" of the communist Poland. ${ }^{23}$ The same model was proposed for the perception of the first half of the century, i.e., the times of regained independence and restored statehood. ${ }^{24}$ It was highly selective, evidently based on a particular axiological pattern of temporality. Answers to the question about it, only in part conditioned by politics, make the key to the ambiguity of Poland under communism since referring to the decade when the avant-garde was born, we may easily realize that it was not dominant or the most attractive for the common public and intellectuals. Józef Czajkowski's social project of the "new art" (Szczuka gave his art the same name) included housing, urban planning, interior design, and applied art, i.e., the aspect of practical application, which Szczuka ignored. ${ }^{25}$ Another exemplary figure was the painter Jan Cybis, cooperating with the futurists and Strzemiński, who struggled to liberate art from the sense of social and political mission, so characteristic of the Young Poland. His radical idea of the autonomy of painting was a unique variant of the modernist art in the sense preferred by Piotrowski. Today no book is available either on Czajkowski or Cybis, while both of them pointed at the border conditions of contemporary Polish art.

Still, there is another model key related to the concept of realism as it was presented by Grabska who interpreted the approaches of Andrzej Wróblewski and Marek Oberländer at the conference of the Association of Art Historians in 1984, remembering also Juliusz Starzyński and Michał Walicki, who had similar opinions about realism in Polish art. ${ }^{26}$ Their realism was quite different from that connected with the avant-garde in the op-ed in Sztu$\mathrm{k} a$ from 1975. The gist of that model can be reduced to Grabska's quote from

${ }^{23}$ The key moment came in 1966, with the climax of the authorities' conflict with the Roman Catholic Church, riots in downtown Warsaw, and putting a copy of the painting of Holy Mary of Częstochowa under arrest. That iconoclastic arrest resembled an act of conceptual art. In 1966, the authorities also gave their consent to hold "Sympozjum Pulawskie," open the Foksal Gallery, and appoint a new director of Museum of Art in Łódź.

${ }^{24}$ This is how I interpret texts by Andrzej Szczerski, engaged in the celebration of the "Centennial of the Avant-Garde," who stressed the patriotic bias of the innovators from the interwar period, with a suggestion that the present authorities of Poland should adopt such a point of view.

${ }_{25}$ Czajkowski referred to the English Arts and Crafts Movement which also contributed to the origin of the avant-garde, although Polish scholars tend to ignore it.

26 E. Grabska, "'Puisque réalisme il y a,' czyli o tym co w sztuce powojennego dziesięciolecia nie mogło się wydarzyć," in: Sztuka polska po 1945 roku, pp. 375-384. 
Michelet: "C'est par vous que le peuple pourra parler au peuple." 27 In comparison to the ordering narration of the nineteenth-century art and the twentieth-century narration of writing about art, this perspective in quite unique in Polish art history since, as Grabska would put it, it took into consideration "the artist's contact with his own time." Besides, it also takes into account social stratification which has been confirmed today by the results of democratic elections - a privilege that was rare in Poland in the past centuries, always a troublesome challenge to artists.

An urgent postulate to make a new lexicon of concepts for the history of Polish art or a generalized panorama of the Polish art of the past century, including various narratives, can be easily challenged by today's new humanities. Many case studies, Clifford Geertz's thick description, grounded theory, a network of neologisms, and new theories developed on that combined foundation are now a new research standard. ${ }^{28}$ But also this local, "insular" strategy, which is not yet the continental mainland, may actually affect the a priori model of ordering Polish history of the most recent art in terms of "development," "emancipation," and the "avant-garde." I believe that an alternative could be provided by a sequel to Anna Markowska's book Definiowanie sztuki - objaśnianie świata. O pojmowaniu sztuki w PRL-u [Defining Art - Explaining the World. On Understanding Art in Communist Poland], ${ }^{29}$ and such a sequel may be Piotr Juszkiewicz's forthcoming study of the national element in Polish experimental art of the early $20^{\text {th }}$ century. Panoramic views also give us a chance to locate the positions of particular members of the debate and define leading research strategies, since the attention that we pay to concepts, which I stressed at the beginning of the present essay after Bal, turns out more significant than the scholarly standard - art historians in Poland have their institutional limitations and represent, fortunately, various political opinions.

In the final quarter of the $20^{\text {th }}$ century, the concepts of the avant-garde and modernism were differently articulated in Warsaw (Juszczak, Grabska), Poznań (Turowski, Piotrowski), Łódź (Stanisławski, Turowski), and Cracow (Porębski). The differences were not focused on encyclopedic definitions but on culture. The Institute of Art History at Adam Mickiewicz University in Poznan was the main point of reference for the debate, yet geography must not make us ignore generational differences. The younger generation of scholars presents a variety of positions: Tomasz Załuski from Łódź has

27 Sztuka polska po 1945 roku, p. 380.

${ }_{28}$ See E. Domańska, “Jakiej metodologii potrzebuje współczesna humanistyka?," Teksty Drugie 2010, 1-2, pp. 45-55.

29 A. Markowska, Definiowanie sztuki - objaśnianie świata. O pojmowaniu sztuki w PRL-u, Katowice 2003. 
been challenging the opposition of the avant-garde and modernism, included in Piotrowski's Znaczenia modernizmu; Wiktoria Kozioł from Cracow has been questioning the critical quality of the art of resistance; Jakub Banasiak from Warsaw has been distancing himself from Piotrowski. Even if Piotr Słodkowski and Luiza Nader share the assumptions of the author of Znaczenia modernizmu, the results of their meticulously conducted research based on records and archives are quite different. Thus, the postulate to make a new lexicon of concepts and write new overviews should be supplemented with another one - to come up, possibly soon, with a history of Polish art history in the $20^{\text {th }}$ and $21^{\text {st }}$ centuries, particularly that the Poznań Institute will figure in such a history quite prominently.

\section{BIBLIOGRAPHY}

Bal M., Traveling Concepts in the Humanities. A Rough Guide, Toronto 2002

Borowski W., "Pseudoawangarda," Kultura 1975, 12

Bryl M., Suwerenność dyscypliny. Polemiczna historia historii sztuki od 1970 roku, Poznań 2008

Bürger P., Teoria awangardy, Kraków 2005

Domańska E., "Jakiej metodologii potrzebuje współczesna humanistyka?" Teksty Drugie 2010, 1-2

Foster H., "O idei sztuki politycznej," trans. E. Mikina, Magazyn Sztuki 1994, 4

Giżycki M., Postmodernizm - kultura wyczerpania?, Warszawa 1988

Grabska E., "Moderne" i straż przednia. Apollinaire wśród krytyków i artystów 19001918, Kraków 2003

Groys B., Gesamtkunstwerk Stalin, München 2008

Jencks Ch., Architektura postmodernistyczna, trans. B. Gadomska, Warszawa 1987

Juszczak W., Teksty o malarzach. Antologia polskiej krytyki artystycznej 1890-1918, Ossolineum 1976

Kluszczyński R., Awangarda - rozważania teoretyczne, Łódź 1997

Koselleck R., Begriffsgeschichten. Studien zur Semantik und Pragmatik der politischen und sozialen Sprache, Berlin 2011

Malarstwo polskie, Modernizm, eds. W. Juszczak, M. Liczbińska, Warszawa 1977

Markowska A., Definiowanie sztuki - objaśnianie świata. O pojmowaniu sztuki w PRL-u, Katowice 2003

Morawski S., Na zakręcie od sztuki do po-sztuki, Kraków 1985

Odkrywanie modernizmu, ed. R. Nycz, Kraków 1998

Olszewski A., Nowa forma w architekturze polskiej 1900-1925. Teoria i praktyka, Wrocław 1967

Orska J., Przełom awangardowy $w$ dwudziestowiecznym modernizmie w Polsce, Kraków 2004

Piotrowski P., Znaczenia modernizmu. W stronę historii sztuki polskiej po 1945 roku, Poznań 1999 
Piotrowski P., "O horyzontalnej historii sztuki," Artium Quaestiones 2009, 20, pp. 59-73

Piotrowski P., In the Shadow of Yalta. Art and the Avant-Garde in Eastern Europe 1945-1989, trans. A. Brzyski, London 2011

Piotrowski P., Globalne ujęcie sztuki Europy Wschodniej, Poznań 2018

Porębski M., "Dwa programy (z problematyki formalizmu w plastyce polskiej dwudziestolecia międzywojennego)," Materiały do Studiów i Dyskusji z Zakresu Teorii i Historii Sztuki, Krytyki Artystycznej oraz Metodologii Badań nad Sztuka 1950, 1, pp. $51-76$

Przybylski R., Klasycyzm, czyli prawdziwy koniec Królestwa Polskiego, Warszawa 1983

Sławiński J., Koncepcja języka poetyckiego awangardy krakowskiej, Wrocław 1965

Spychalski M., "Na straży awangardy," Odra 2014, 4

Sztuka polska po 1945 roku. Materiały Sesji Stowarzyszenia Historyków Sztuki, Warszawa, listopad 1984, ed. T. Hrankowska, Warszawa 1987

Turowski A., W kręu konstruktywizmu, Warszawa 1979

Turowski A., Konstruktywizm polski. Próba rekonstrukcji nurtu (1921-1934), Wrocław 1981

Turowski A., Wielka utopia awangardy: artystyczne i społeczne utopie w sztuce rosyjskiej 1910-1930, Warszawa 1990

Turowski A., Awangardowe marginesy, Warszawa 1998

Turowski A., Budowniczowie świata. Z dziejów radykalnego modernizmu w sztuce polskiej, Kraków 2000

Turowski A., Parowóz dziejów, Warszawa 2012

Włodarczyk W., Socrealizm. Sztuka polska w latach 1950-1954, Paryż 1986

Włodarczyk W, "Kiedy zaczęło się 'dzisiaj'? O źródłach sztuki polskiej lat dziewięćdziesiątych," in: Sztuka dzisiaj, Warszawa 2002

Włodarczyk W., "Pięć lat," in: Zaraz po wojnie, eds. J. Kordjak, A. Szewczyk, Warszawa 2015

Włodarczyk W., "Artysta nowoczesny jako t.w.," Miejsce. Studia nad sztukq i architektura XX i XXI wieku 2015, 1, pp. 89-108

Wybory i ryzyka awangardy. Studia z teorii awangardy, eds. U. Czartoryska, R. W. Kluszczyński, Warszawa-Eódź 1985, pp. 7-26

Wojciech Włodarczyk

Academy of Fine Arts, Warsaw

\section{ON THE CONCEPT OF MODERNISM}

Summary

The author argues that the significance of the year 1989 for Polish art was not determined by political changes, but by the rise of postmodernism. Until that moment, the term "modernism" usually referred in academic art history to Polish art at the turn of the $20^{\text {th }}$ century. The concept of postmodernism brought to the Polish language 
a new meaning of modernism as simply modern art, and more precisely, as modern art defined by Clement Greenberg. That change made it necessary to draw a new map of concepts referring to modern Polish art, most often defined before by the concept of the avant-garde. In Mieczysław Porębski's essay "Two Programs" [Dwa programy] (1949), and then, since the late 1960s, in Andrzej Turowski's publications, the concept of the avant-garde was acknowledged as basic for understanding twentieth-century Polish art. The significance of the concept of the avant-garde in reference to the art of the past century in Poland changed after the publication of Piotr Piotrowski's book of 1999, Meanings of Modernism [Znaczenia modernizmu]. Piotrowski challenged in it the key role of that concept - e.g., Władysław Strzemiński and Henryk Stażewski, usually called avant-gardists before, were considered by him modernists - in favor of a new term, "critical art," referring to the developments in the 1990. In fact, critical art continued the political heritage of the avant-garde as the radical art of resistance. The author believes that such a set of terms and their meanings imposes on the concept of the avant-garde some limits, as well as suggests that scholars and critics use them rather inconsistently. He argues that concepts should not be treated as just label terms, but they must refer to deeper significance of tendencies in art. He mentions Elżbieta Grabska's term "realism," also present in the tradition of studies on modern Polish art, and concludes with a postulate of urgent revision of the relevant vocabulary of Polish art history.

Keywords:

history of Polish art, vocabulary, modernism, postmodernism, avant-garde 